\title{
Evaluation of cytotoxicity and oxidative DNA damaging effects of di(2-ethylhexyl)-phthalate (DEHP) and mono(2-ethylhexyl)-phthalate (MEHP) on MA-10 Leydig cells and protection by selenium
}

\author{
Pinar Erkekoglu ${ }^{\mathrm{a}, \mathrm{b}}$, Walid Rachidi a , Ozge Gursoy Yuzugullu ${ }^{\mathrm{c}, \mathrm{d}}$, Belma Giray ${ }^{\mathrm{b}}$, Alain Favier ${ }^{\mathrm{a}}$, \\ Mehmet Ozturk ${ }^{\mathrm{c}, \mathrm{d}}$, Filiz Hincal ${ }^{\mathrm{b}, *}$ \\ a CEA Grenoble, INAC/SCIB/LAN, 17 Rue des Martyrs, 38054 Grenoble Cedex 9, France \\ ${ }^{\mathrm{b}}$ Hacettepe University, Faculty of Pharmacy, Department of Toxicology, 06100 Ankara, Turkey \\ c Department of Molecular Biology and Genetics, Bilkent University, 06800 Ankara, Turkey \\ ' Centre de Recherche INSERM-Université Joseph Fourrier U823, Institut Albert Bonniot, 38042 Grenoble, France
}

\section{A R T I C L E I N F O}

Article history:

Received 30 April 2010

Revised 14 July 2010

Accepted 19 July 2010

Available online 24 July 2010

Keywords:

Di(2-ethylhexyl)-phthalate

Mono(2-ethylhexyl)-phthalate

Selenium

Oxidative stress

p53

Cytotoxicity

Antioxidant enzymes

Comet assay

\begin{abstract}
A B S T R A C T
Di(2-ethylhexyl)-phthalate (DEHP) is the most abundantly used phthalate derivative, inevitable environmental exposure of which is suspected to contribute to the increasing incidence of testicular dysgenesis syndrome in humans. Oxidative stress and mitochondrial dysfunction in germ cells are suggested to contribute to phthalate-induced disruption of spermatogenesis in rodents, and Leydig cells are one of the main targets of phthalates' testicular toxicity. Selenium is known to be involved in the modulation of intracellular redox equilibrium, and plays a critical role in testis, sperm, and reproduction. This study was aimed to investigate the oxidative stress potential of DEHP and its consequences in testicular cells, and examine the possible protective effects of selenium using the MA-10 mouse Leydig tumor cell line as a model. In the presence and absence of selenium compounds [ $30 \mathrm{nM}$ sodium selenite (SS), and $10 \mu \mathrm{M}$ selenomethionine (SM)], the effects of exposure to DEHP and its main metabolite mono(2-ethylhexyl)phthalate (MEHP) on the cell viability, enzymatic and non-enzymatic antioxidant status, ROS production, p53 expression, and DNA damage by alkaline Comet assay were investigated. The overall results of this study demonstrated the cytotoxicity and genotoxicity potential of DEHP, where MEHP was found to be more potent than the parent compound. SS and SM produced almost the same level of protection against antioxidant status modifying effects, ROS and p53 inducing potentials, and DNA damaging effects of the two phthalate derivatives. It was thus shown that DEHP produced oxidative stress in MA-10 cells, and selenium supplementation appeared to be an effective redox regulator in the experimental conditions used in this study, emphasizing the critical importance of the appropriate selenium status.
\end{abstract}

(c) 2010 Elsevier Inc. All rights reserved.
Abbreviations: BCA, bicinchoninic acid assay.; CDNB, 1-chloro-2,4 dinitrobenzene.; $\mathrm{CM}-\mathrm{H}_{2}$ DCFA, 5-(and 6-) chloromethyl-2',7'-dichlorodihydrofluorescein diacetate; DAB, 3,3'-diaminobenzidine.; DCFH, 2',7'-dichlorofluorescin.; DCF, 2', 7'-dichlorofluorescein.; DEHP, di(2-ethylhexyl) phthalate.; DMEM/F-12, Dulbecco's Modified Eagle Medium (1:1) Nutrient Mixture.; DMSO, dimethyl sulfoxide.; DTNB, 5,5'-dithiobis(2nitrobenzoic) acid.; FBS, fetal bovine serum.; GPx1, cytosolic glutathione peroxidase. GPx4, phospholipid hydroperoxide glutathione peroxidase.; GR, glutathione reductase; GSH, glutathione.; GSSG, oxidized glutathione.; GST, glutathione S-transferase.; $\mathrm{H}_{2} \mathrm{Se}$ hydrogen selenide.; hcG, human chorionic gonadotrophin.; MEHP, mono(2-ethylhexyl) phthalate.; MTT, 3-(4,5-dimethyl-thiazol-2-yl)-2,5-diphenyl-tetrazolium bromide.; $\mathrm{Na}_{2}$-EDTA, disodium ethylenediaminetetraacetic acid.; NADPH, nicotinamide adenine dinucleotide phosphate, reduced form.; p53, protein 53.; PBS, phosphate-buffered saline.; PP, peroxisome proliferators.; PPAR $\alpha$, peroxisome proliferator-activated receptor $\alpha$.; PPAR $\beta$, peroxisome proliferator-activated receptor $\beta$.; PPAR $\gamma$, peroxisome proliferator-activated receptor $\gamma$.; ROS, reactive oxygen species.; Se, selenium.; SEM, standard error of mean.; Sepp1, selenoprotein P.; SM, selenomethionine.; SS, sodium selenite.; TNB, 5-thio-2-nitrobenzoic acid.; TrxR, thioredoxin reductase.

* Corresponding author. Fax: +90 3123092958

E-mail address: fhincal@tr.net (F. Hincal).

\section{Introduction}

Phthalic acid esters are the most abundantly produced plasticizers, and known as endocrine disruptors and peroxisome proliferators (PP). Their inevitable environmental exposures in humans have been suspected to contribute to the increasing incidence of testicular dysgenesis syndrome (TDS) that is a range of reproductive defects including cryptorchidism and hypospadias in newborn boys, and testicular cancer and reduced sperm quality in adult males (Swan, 2008). In fact, TDS has been shown to develop in male rats that are exposed to phthalates in utero (Fisher et al., 2003). Di(2-ethylhexyl)phthalate (DEHP) is the most important phthalate derivative with its high production, use and occurrence in the environment. It is mainly used in polyvinyl chloride plastics in the form of numerous consumer and personal care products and medical devices. The typical human exposure to DEHP ranges from 3 to $30 \mu \mathrm{g} / \mathrm{kg} /$ day (Doull et al., 1999) but, can be exceeded in specific medical conditions reaching $1.5 \mathrm{mg} /$ 
$\mathrm{kg}$ /day exposure in hemodialysis patients, or as high as $10-20 \mathrm{mg} /$ $\mathrm{kg} /$ day during neonatal transfusion or parenteral nutrition (Loff et al., 2000; Kavlock et al., 2005).

The mechanisms by which phthalates and specifically DEHP exert their toxic effects in reproductive system are not yet fully elucidated. Some of the effects of phthalate are related to their anti-androgenic potential (Ge et al., 2007; Noriega et al., 2009). A peroxisome proliferator-activated receptor $\alpha$ (PPAR $\alpha$ )-mediated pathway based on their PP activity (Gazouli et al., 2002), and activation of metabolizing enzymes leading to free radical production and oxidative stress have also been suggested (O'Brien et al., 2005). Although Sertoli cells were thought to be the primary targets of phthalate exposure in testis (Grasso et al., 1993), available data suggest that Leydig cells are one of the main targets (Ge et al., 2007). Leydig cells are the primary source of testosterone production in males, and differentiation of Leydig cells in the testes is one of the primary events in the development of the male body and fertility (Zhang et al., 2008). Using the MA-10 mouse Leydig tumor cell line as a model system may, therefore, offer a valuable model in studying the direct effects of environmental chemicals, particularly those of endocrine disruptors on Leydig cell function in vitro. MA-10 cells are by far the best characterized and more widely used lines of cultured Leydig tumor cells that were independently derived from the M5480 tumor, a hormonally responsive mouse Leydig tumor (Ascoli, 1981).

The essential trace element selenium (Se), is the important component of cellular antioxidant defense and is involved in the modulation of intracellular redox equilibrium with its some 25 forms of cellular selenoproteins, particularly with glutathione peroxidases (GPx), and thioredoxin reductases (TrxR) (Oberley et al., 2000). Se is actively involved in many fundamental biological processes ranging from immune functions to apoptosis, and protection and repair of DNA (Ganther, 1999). It is essential for the production of normal spermatozoa and thus plays a critical role in testis, sperm, and reproduction (Flohé, 2007). The major role of Se in fertility is mediated by the membrane bound phospholipid hydroperoxide glutathione peroxidase (GPx4) which is the most abundant selenoprotein in testis (Flohé, 2007; Ursini et al., 1999). Testis Se is known to be remarkably and preferentially maintained in Se deficiency. Severe and prolonged deficiency results in sterility as spermatogenesis was arrested, whereas in less severe Se deprivation reduced sperm motility leading to impaired fertilization capacity and abnormal sperm morphology were reported (Maiorino et al., 2006). On the other hand, epidemiological studies have suggested that low serum Se levels were associated with an increase in the incidence of cancer (Clark et al., 1991). The chemopreventive and chemotherapeutic mechanisms of Se still remain unclear. Protection against oxidative damage, induction of apoptosis secondary to production of reactive oxygen species (ROS), and regulation of the thioredoxin (Trx) redox system are among the many potential mechanisms proposed (Combs and Gray, 1998; Ganther, 1999; Kitahara et al., 1993) which also seem to be closely related to the roles of Se in the reproductive system.

Oxidative stress and, thus, ROS play an important role in the modulation of several important physiological functions, but also accounts for changes that can be detrimental to the cells (Dröge, 2002). ROS are shown to contribute to cellular damage, apoptosis and cell death, but also involved in regulation of gene expression by controlling signal transduction through direct participation in cell signaling, and/or modulation of cell redox state (Dalton et al., 1999; Finkel, 1998). ROS have also been suspected of being involved in the formation of testicular atrophy in phthalate-exposed rats (Kasahara et al., 2002). On the other hand, p53 tumor suppressor protein is a redox sensitive protein known to play important roles in controlling the integrity and correctness of all processes in each individual cell. Activation of p53 by ROS and exogenous DNA damages can lead to growth arrest of the cell, DNA repair induction or apoptosis (Kim et al., 2009). Several environmental chemicals including phthalates have been shown to induce apoptosis in the reproductive tract of rodents through p53 induction (Chandrasekaran and Richburg, 2005).

On the basis of these knowledge and available data, it seems useful to examine modulation of cellular redox by Se and whether Se supplementation is effective on the effects of phthalates in rat reproductive system. In the current study, MA-10 mouse Leydig cells cultured with and without Se supplementation were used as a model, and the effects of exposure to DEHP and its major metabolite MEHP on the viability, enzymatic and non-enzymatic antioxidant status, ROS production, p53 expression and DNA damage were investigated.

\section{Materials and methods}

Chemicals. MEHP was obtained from Cambridge Isotope Laboratories ${ }^{\circledR}$ (Andover, MA, USA). The protein assay kit was from Uptima Interchim ${ }^{\circledR}$ (Montluçon, France). $\mathrm{NaOH}$ was purchased from Carlo Erba ${ }^{\circledR}$ (Rodano, Italy). Dulbecco's modified Eagle medium (1:1) nutrient mixture (DMEM/F-12) was purchased from Gibco ${ }^{\circledR}$ (Courbevoie, France). 5-(and 6-) chloromethyl-2',7'-dichlorodihydrofluorescein diacetate $\left(\mathrm{CM}-\mathrm{H}_{2} \mathrm{DCFA}\right)$ was purchased from Molecular Probes Detection Technologies, Invitrogen ${ }^{\circledR}$ (Eugene, OR, USA). The EnVision Plus staining kit was purchased from Dako ${ }^{\circledR}$ (Carpinteria, CA, USA). All the other chemicals including DEHP, sodium selenite (SS), selenomethionine (SM), dimethyl sulfoxide (DMSO), 3-(4,5-dimethylthiazol-2-yl)-2,5-diphenyl-tetrazolium bromide (MTT), 5,5'-dithiobis (2-nitrobenzoic) acid (DTNB), 1-chloro-2,4 dinitrobenzene (CDNB), fetal bovine serum (FBS), Mayers hematoxylin nuclear stain, and saponin from quillaja bark; colorimetric assay kits for thioredoxin reductase (TrxR), and glutathione (GSH) measurements; Cell Lytic M cell lysis reagent, protease inhibitor cocktail, were obtained from Sigma-Aldrich ${ }^{\circledR}$ (St. Louis, MO, USA). Anti-p53, the mouse monoclonal antibody, sc-263 was obtained from Santa Cruz Biotechnology Inc ${ }^{\circ}$ (Santa Cruz, California, USA). The goat anti-mouse horseradish peroxidase (HRP) conjugated secondary antibody was purchased from Invitrogen Molecular Probes ${ }^{\circledR}$ (Oregon, USA).

Cell culture and treatment. MA-10 mouse Leydig tumor cells were a generous gift from Prof. Mario Ascoli (Department of Pharmacology, University of Iowa College, Iowa City, USA) and maintained in Waymouth medium containing $15 \%(\mathrm{v} / \mathrm{v})$ heat-inactivated horse serum, and $50 \mu \mathrm{g} / \mathrm{mL}$ gentamicin as previously described (Ascoli, 1981). Culturing of the MA-10 cells were accomplished in DMEM/F12 (1:1) medium supplemented with 15\% horse serum and gentamicin $(50 \mu \mathrm{g} / \mathrm{ml})$ using gelatin-coated culture flasks, at $37{ }^{\circ} \mathrm{C}$ in a humidified incubator under $5 \% \mathrm{CO}_{2}$. For sub-cultivation cells were trypsinized, washed with sterile phosphate-buffered saline (PBS) and centrifuged at $1500 \times g$ for $5 \mathrm{~min}$. For the experiments only the cells of 10-12 passages were used.

SS and SM stock solutions were prepared in sterile, deionized water. DEHP $(50 \mathrm{mM})$ and MEHP $(100 \mu \mathrm{M})$ stock solution were prepared in $0.1 \%$ DMSO, and fresh dilutions were made using culture medium to achieve final concentrations ranging from 1 to $10 \mathrm{mM}$ for DEHP and from 1 to $10 \mu \mathrm{M}$ for MEHP. Cell viability measurements were performed in MA-10 cells incubated with various concentrations of DEHP or MEHP for $24 \mathrm{~h}$. For the assessment of protective effect of Se, MA-10 cells supplemented with $30 \mathrm{nM}$ SS or $10 \mu \mathrm{M}$ SM were cultured for $72 \mathrm{~h}$, then exposed to various concentrations of DEHP or MEHP for $24 \mathrm{~h}$ while continuing the Se supplementation. The doses of Se in the form of SS and SM used in this study were chosen from preliminary experiments (not shown) as concentrations do not inhibit cell growth and do not cause cytotoxicity, but result in maximal GPx1 induction after $72 \mathrm{~h}$ of incubation.

For the measurement of enzyme activities, ROS and total GSH levels, p53 expression, and for alkaline single-cell gel electrophoresis (SCGE, Comet assay), following treatment groups of MA-10 cells were prepared: Non-treated cells (NT-C): MA-10 cells were cultured 
without any treatment for $72 \mathrm{~h}$; SS-supplemented cells (SS-S): MA-10 cells were cultured with $30 \mathrm{nM}$ SS for $72 \mathrm{~h}$; SM-supplemented cells (SM-S): MA-10 cells were cultured with $10 \mu \mathrm{M}$ SM for $72 \mathrm{~h}$; DEHPtreated cells (DEHP-T): MA-10 cells were cultured with $3 \mathrm{mM}$ DEHP for $24 \mathrm{~h}$; DEHP-treated SS-S cells (SS/DEHP-T): SS-S cells were cultured with $3 \mathrm{mM}$ DEHP for $24 \mathrm{~h}$; DEHP-treated SM-S cells (SM/ DEHP-T): SM-S cells were cultured with $3 \mathrm{mM}$ DEHP for $24 \mathrm{~h}$; MEHPtreated cells (MEHP-T): MA-10 cells were cultured with $3 \mu \mathrm{M}$ MEHP for $24 \mathrm{~h}$; MEHP-treated SS-S cells (SS/MEHP-T): SS-S cells were cultured with $3 \mu \mathrm{M}$ MEHP for $24 \mathrm{~h}$; MEHP-treated SM-S cells (SM/ MEHP-T): SM-S cells were cultured with $3 \mu \mathrm{M}$ MEHP for $24 \mathrm{~h}$.

Determination of cell viability. Cell viability was determined by a modified MTT assay (Cory et al., 1991), in conjunction with trypan blue counting. 3000 cells per well were plated onto 96-well microtiter plates in $200 \mu \mathrm{L}$ medium with or without DEHP, MEHP, SS or SM. After incubation for specified times at $37{ }^{\circ} \mathrm{C}$ in a humidified incubator, the medium was removed, cells were washed twice with PBS and $20 \mu \mathrm{L}$ of MTT ( $5 \mathrm{mg} / \mathrm{mL}$ in PBS) was added to each well. The medium was removed $2 \mathrm{~h}$ later, $200 \mu \mathrm{L}$ of DMSO was added to dissolve the formazan product and the absorbance was read at $570 \mathrm{~nm}$ using Multiscan Ascent microtiter plate reader (Labsystems, France). The absorbance was proportional to viable cell number, and cell survival was calculated as the percentage of the staining values of untreated cultures. The percentage viability was calculated as "\% specific viability $=[(A-B) /$ $(C-B)] / 100$ " where $A=$ absorbance of the treated cells at $570 \mathrm{~nm}$, $B=$ absorbance of the medium at $570 \mathrm{~nm}$, and $C=$ absorbance of the control cells at $570 \mathrm{~nm}$.

Antioxidant enzyme assays and glutathione levels. After specified incubation periods and trypsinization, cells were lysed using Cell Lytic M Cell Lysis agent with a protease inhibitor cocktail, and then centrifuged at $4000 \mathrm{rpm}, 4^{\circ} \mathrm{C}$ for $10 \mathrm{~min}$. After further centrifugation at $13.000 \mathrm{rpm}, 4^{\circ} \mathrm{C}$, for $20 \mathrm{~min}$, antioxidant enzyme activities and GSH levels were measured in the supernatant.

The activity of cytosolic GPx (GPx1) was measured in a coupled reaction with glutathione reductase (GR) as described earlier (Flohé and Günzler, 1984; Günzler et al., 1974). The assay is based on the instant and continous reduction of oxidized glutathione (GSSG) formed during GPx1 reaction by an excess of GR activity providing for a constant level of GSH. As a substrate, t-butyl hydroperoxide used and concominant oxidation of NADPH was monitored spectrophotometrically at $340 \mathrm{~nm}$. One unit of enzyme was defined as the amount of GPx 1 that transformed $1 \mu \mathrm{mol}$ of NADPH to NADP per minute at $37^{\circ} \mathrm{C}$.

Cytosolic TrxR activity was determined colorimetrically using Thioredoxin Reductase Assay kit. As described previously (Arner et al., 1999), the method is based on the reduction of DTNB with NADPH to 5-thio-2-nitrobenzoic acid (TNB) that is measured at $412 \mathrm{~nm}$. One unit of TrxR activity was defined as the enzyme that caused an increase in $\mathrm{A}_{412}$ of 1.0 per minute per $\mathrm{mL}$ at $\mathrm{pH} 7.0$ at $25^{\circ} \mathrm{C}$.

Cytosolic glutathione-S-transferase (GST) activity was determined according to the method of Habig et al. (1974) using CDNB as a substrate and measuring the change in absorbance at $340 \mathrm{~nm}$. The results were given as $\mathrm{nmol} / \mathrm{min} / \mathrm{mg}$ protein.

For the measurement of the total GSH levels, cells were diluted with 5-sulphosalicylic acid for protein precipitation, and centrifuged at $4000 \mathrm{rpm}, 4^{\circ} \mathrm{C}$, for $10 \mathrm{~min}$. Supernatants were used for total GSH determinations by using Glutathione Assay kit. The assay was based on the reduction of DTNB by NADPH by a reaction catalyzed by GR using GSH at $412 \mathrm{~nm}$ (Akerboom and Sies, 1981). The results were given as $\mathrm{pmol} \mathrm{GSH} / \mathrm{mg}$ protein.

Protein content of the samples was determined by bicinchoninic acid assay (BCA) using a protein assay kit (Krieg et al., 2005). The results were given as $\mathrm{mg} / \mathrm{mL}$ protein.
Measurement of intracellular ROS production. Total intracellular ROS production was measured using peroxide sensitive fluorescent probe CM- $\mathrm{H}_{2}$ DCFA as described earlier (Loikkanen et al., 1998). The study was conducted in the dark, and $70-80 \%$ confluent cells were used. MA-10 cells seeded in 96-well plates with/without SS (30 nM) and SM (10 $\mu \mathrm{M})$ incubated at $37^{\circ} \mathrm{C}$ in a humidified incubator under $5 \% \mathrm{CO}_{2}$ for $72 \mathrm{~h}$. After removal of the culture media, cells were loaded with $\mathrm{CM}-\mathrm{H}_{2} \mathrm{DCFA}$ in PBS buffer for $30 \mathrm{~min}$ at room temperature. The cellular esterase activity results in the formation of the nonfluorescent compound, the $2^{\prime}, 7^{\prime}$-dichlorofluorescin (DCFH). DCFH is rapidly oxidized in the presence of ROS to a highly fluorescent $2^{\prime}, 7^{\prime}$-dichlorofluorescein (DCF). The cells were washed, then incubated with with/without DEHP $(3 \mathrm{mM})$ or MEHP $(3 \mu \mathrm{M})$ at $37^{\circ} \mathrm{C}$ in a humidified incubator under $5 \% \mathrm{CO}_{2}$ for 0,30 and $60 \mathrm{~min}$. DCF fluorescence was measured with a PerkinElmer Victor 31420 multiwell fluorometer (Perkin Elmer ${ }^{\circledR}$, Buckinghamshire, UK) at an excitation wavelength of $485 \mathrm{~nm}$ and an emission wavelength of $535 \mathrm{~nm}$. After data acquisition, Wallac 1420 Manager software was used to analyze ROS production. Background fluorescence was obtained from cell-free wells containing $5 \mu \mathrm{M}$ DCF in $0.5 \mathrm{~mL}$ of PBS and subtracted from the fluorescence values found. The multiwell plate was kept in a cell culture incubator between the measurements. The exposures were repeated 3-4 times with three parallel measurements. Fluorescence values were normalized to the cell numbers. For each condition, 8-wells with triplicate measurements were used and the mean of three independent experiments was given as a result.

p53 evaluation by immunocytochemistry. The expression of p53 in MA-10 cells was examined immunocytochemically using the EnVision Plus System. MA-10 cells, treated and cultured as described above, were washed with PBS for 3 min shaking on a shaker gently, and fixed with $4 \%$ formaldehyde in PBS at room temperature. Cells were rinsed with $\mathrm{ddH}_{2} \mathrm{O}$ once, and washed with PBS for $3 \mathrm{~min}$ as were done between each step, then permeabilized with PBS/0.5\% saponin $/ 0.3 \%$ Triton X-100 for 3 times, each 5 min on the shaker. Cells were blocked with PBS/\%10 FBS $/ 0,3 \%$ Triton X-100 at $37{ }^{\circ} \mathrm{C}$ for $1 \mathrm{~h}$, then PBS washed cells were incubated with diluted primary antibody overnight at $4{ }^{\circ} \mathrm{C}$. Secondary antibody was used directly and cells were incubated at $25^{\circ} \mathrm{C}$ for $30 \mathrm{~min}$. Cells were again washed with $1 \times$ PBS and later with $1 \times \mathrm{PBS} / 2 \% \mathrm{FBS} / 0,3 \%$ Triton X-100 3 times, and stained with 3,3'diaminobenzidine (DAB) Chromogen solution. The staining was stopped by adding $\mathrm{ddH}_{2} \mathrm{O}$, and then hematoxylin was used as a nuclear stain. Images were acquired with a DC490 digital camera (Leica, Wetzlar, Germany). Cells were considered to be positive when the brown staining was present in the nucleus. For each condition 3 slides were counted and the results were given as percentage of p53 nuclear stainings.

Alkaline single-cell gel electrophoresis (Comet assay). DNA damage was evaluated using the alkaline Comet assay that allows the measurement of single- and double-strand breaks together with alkali-labile sites. The assay was performed as described earlier (Singh et al., 1988; Tice et al., 2000) and measurements were made in two consecutive days on triplicate slides and the results were given as the mean value of the two days. Immediately after the treatments, the cells were isolated, washed and re-suspended in PBS at a density of $\sim 2.5 \times 10^{6}$ cells $/ \mathrm{ml}$. $50 \mu \mathrm{l}$ of this suspension was mixed with $450 \mu \mathrm{l}$ solution of low melting point agarose ( $0.6 \%$ in PBS), and $100 \mu \mathrm{l}$ of the solution was spread on a microscope slide covered with $1 \%$ agarose. Cells were lysed (2.5 M NaCl, $0.5 \mathrm{M} \mathrm{Na}_{2}$-EDTA, $10 \mathrm{mM}$ Tris, $1 \%$ sodium lauryl sulfate, $1 \%$ Triton $\mathrm{X}-100,10 \%$ DMSO, $\mathrm{pH} 10$ ) at $4{ }^{\circ} \mathrm{C}$ in the dark for $1 \mathrm{~h}$. After lysis, cells were immersed in freshly prepared alkaline electrophoresis buffer ( $300 \mathrm{mM} \mathrm{NaOH}, 1 \mathrm{mM} \mathrm{Na}_{2}$-EDTA, pH 13) for 30 min to allow DNA unwinding. Electrophoresis was then performed at $25 \mathrm{~V} / 300 \mathrm{~mA}$ for $30 \mathrm{~min}$. Slides were rinsed three times for $5 \mathrm{~min}$ with neutralization buffer ( $0.4 \mathrm{M}$ Tris- $\mathrm{HCl}, \mathrm{pH} 7.4)$, and stained with 
ethidium bromide ( $20 \mu \mathrm{g} / \mathrm{mL}$ ) in PBS. For quantification, fluorescence microscope (Carl Zeiss ${ }^{\circledR}$, Germany) was used which was connected to a charge-coupled device (CDC) and a computer-based analysis system (Comet assay IV software, Perceptive Instruments Ltd), and the extent of DNA damage was determined after electrophoretic migration of DNA fragments in the agarose gel. For each condition, 50 randomly selected comets on each slide were scored, and the tail\% intensities (percentage of DNA in the tail) and the tail moments (product of comet length and tail intensity) were determined as an average of triplicate slides.

Statistical analysis. The data were expressed as mean \pm standard error (SEM). Statistical significances of differences among treatment groups were determined by use of one-way analysis of variance and covariance (ANOVA), followed by Student's $t$-test using a Statistical Package for Social Sciences Program (SPSS). A $p$-value $<0.05$ was considered as statistically significant.

\section{Results}

Cell viability

In Fig. 1, cell viability data produced by MTT assay for DEHP-, and MEHP-treated MA-10 cells were presented as relative to zero dose of DEHP or MEHP. DEHP had a flat dose-cell viability response curve, so that MA-10 cells showed $\sim 80$ to $60 \%$ survival at a dose range of $10 \mu \mathrm{M}$ to $0.5 \mathrm{mM}$ DEHP (Fig. 1A). Whereas MEHP was highly toxic at $\mu \mathrm{M}$ range with a very sharp dose-response curve, so that there was no cell survival at doses $10 \mu \mathrm{M}$ and higher (Fig. $1 \mathrm{~B}$ ). The $\mathrm{IC}_{50}$ values for DEHP and MEHP were found to be approximately $3 \mathrm{mM}$ and $3 \mu \mathrm{M}$, respectively. This demonstrated that MEHP, the main metabolite of DEHP, was the main active form in MA-10 cells with an almost 1000fold higher cytotoxicity than the parent compound.

Se supplementation of the cells with either SS (30 nM) or SM $(10 \mu \mathrm{M})$ was protective against the cytotoxic effects of DEHP, and MEHP.

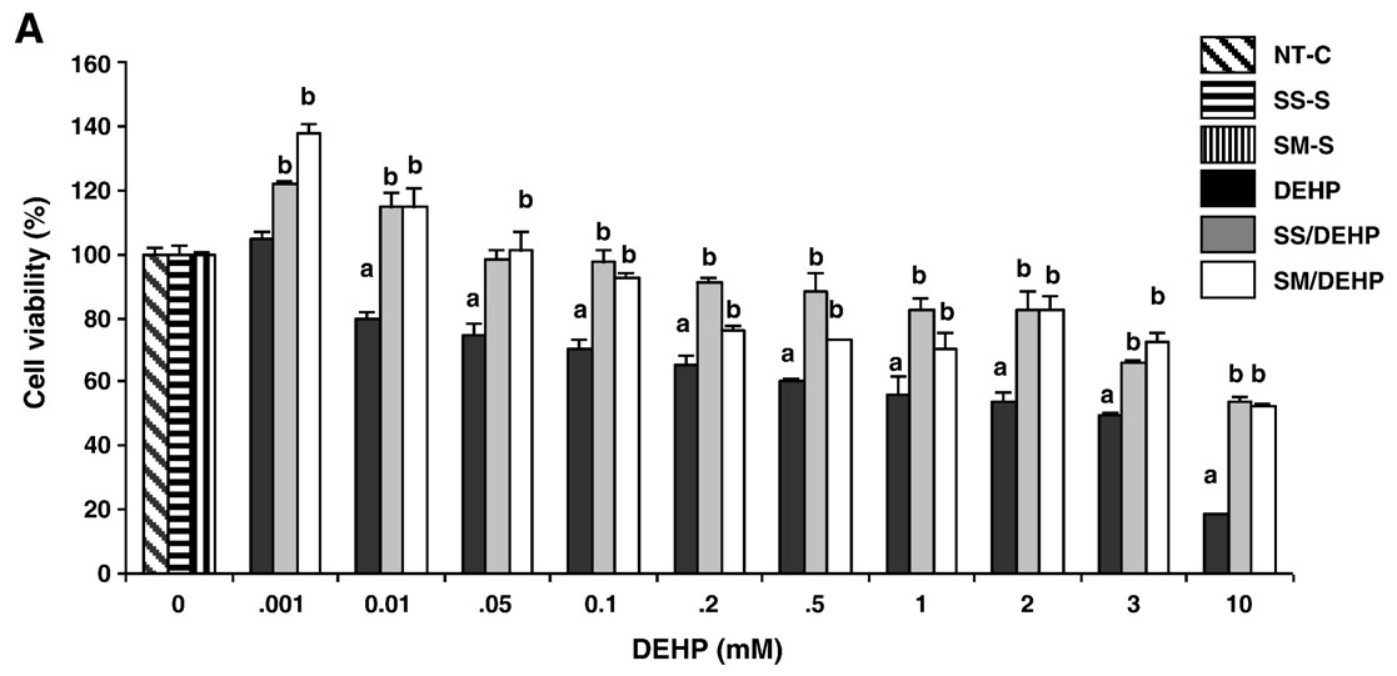

B

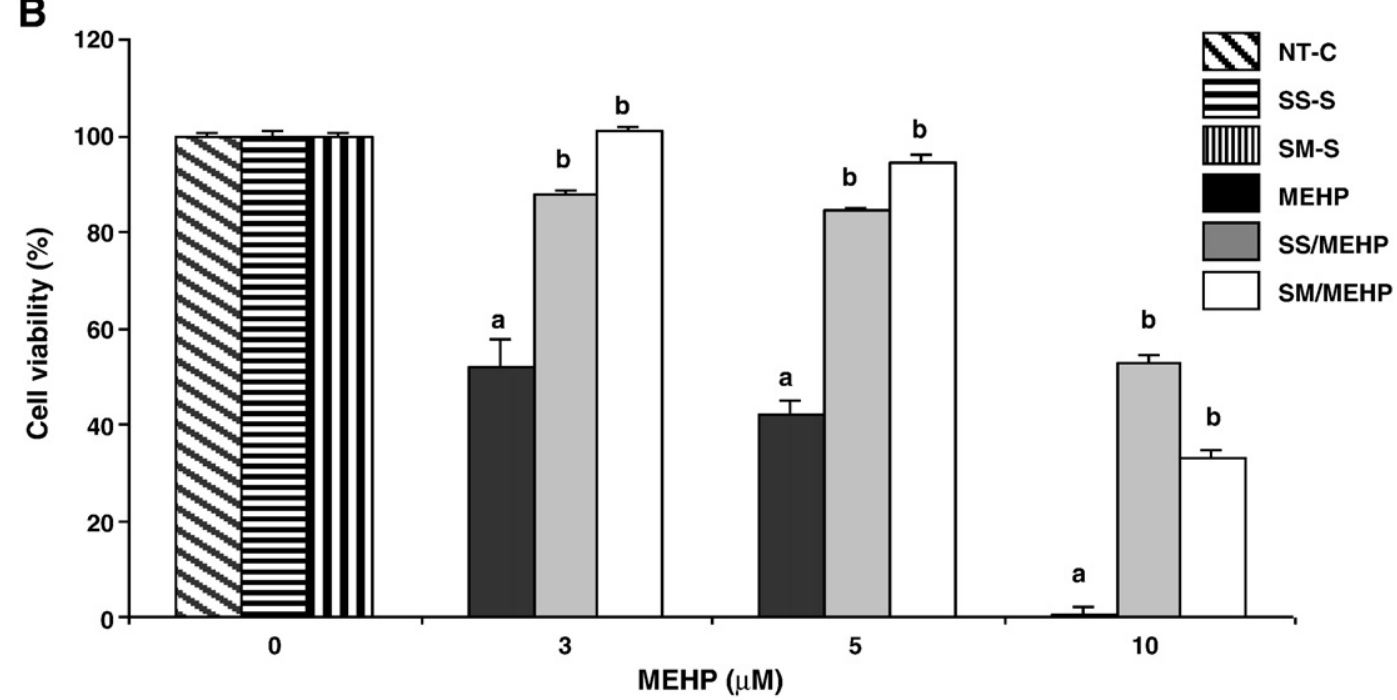

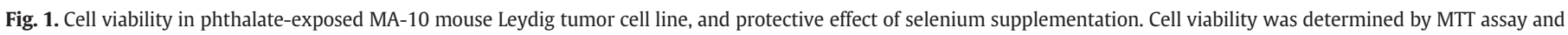

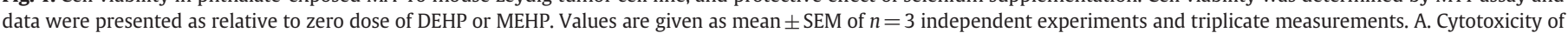

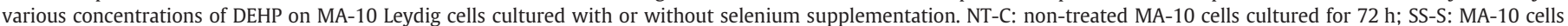

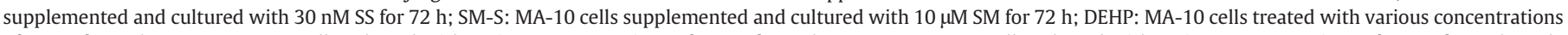

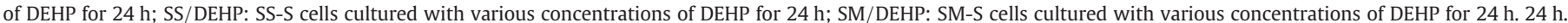

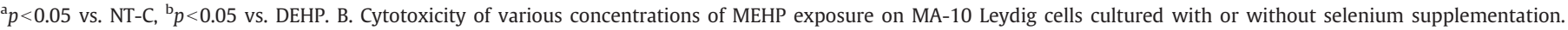

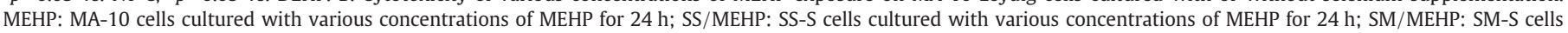
cultured with various concentrations of MEHP for 24 h. ${ }^{a} p<0.05$ vs. NT-C, ${ }^{b} p<0.05$ vs. MEHP. 
In DEHP-exposed cells, for concentrations up to $2 \mathrm{mM}$, Se was highly protective providing $\geq 50 \%$ higher viability, and the effects of SS was higher $(p<0.05)$ than SM at 0.2, 0.5 and $1 \mathrm{mM}$ DEHP exposures. In cells exposed to an $\mathrm{IC}_{50}$ dose of DEHP, both SS and SM forms of Se provided higher viability ( 36 and $48 \%$, respectively, $p>0.05$ ) than DEHP-treated cells (Fig. 1A). Whereas a complete viability as control cells was observed with SM supplementation in MA-10 cells exposed to an $\mathrm{IC}_{50}$ dose of MEHP (Fig. 1B), supplementation with SS maintained the cell viability at a level of $~ 85 \%$ of control cells (NT-C), and the difference of SS and SM effects was significant $(p<0.05)$.

\section{Enzymatic and non-enzymatic antioxidants}

The results of the antioxidant status assessment of MA-10 cells are illustrated in Fig. 2. Se supplementation of MA-10 cells with either SS or SM (that is SS-S and SM-S cells) significantly increased the activities of GPx1 (1.7- and 1.6-fold, respectively) and TrxR ( 1.6- and 1.7-fold, respectively) compared to non-treated control cells (NT-C); but did not cause any change on the total GSH level and GST activity. The difference between the effects of SS and SM was insignificant.

In cells exposed to DEHP or MEHP, GPx1 activity decreased $~ 2.5$ and $~ 4$-fold, respectively (Fig. 2A). Thus, the effect of MEHP was much higher. Se supplementation either with SS or SM in DEHP-exposed cells was able to enhance the GPx1 activity significantly even up to those of SS-S and SM-S cells. In MEHP-exposed cells, SS supplementation maintained the GPx1 activity almost at the control level, whereas the effect of SM was significantly higher than that of SS, elevating the activity of GPx1 to the level of SM-S cells.

The same level of decrease ( 2.4-fold) was observed in cytosolic TrxR activity of MA-10 cells exposed to the parent phthalate or the main metabolite (Fig. 2B). Supplementation of Se with SS was able to elevate the cytosolic TrxR activity of MEHP-exposed cells to the levels of SS-S cells, and with SM to the level of control cells. However, in DEHP-exposed cells, the increase of TrxR activity with Se supplementation was rather low reaching only $\sim 75-80 \%$ of that of control cells.

GST activity also decreased significantly in DEHP-T (60\%) and MEHP-T (53\%) cells. Neither SS nor SM supplementation restored the activity of the cytosolic GST in phthalate-exposed cells. In contrast, Se supplementation in both SS and SM forms decreased the enzyme activity in MEHP-exposed cells. Whereas, GST activity remained the same with the presence of SS, but was found even lower with SM supplementation in DEHP-exposed cells (Fig. 2C).

Total GSH levels decreased significantly in DEHP-T $(\sim 40 \%)$ and MEHP-T ( 42\%) cells (Fig. 2D). Se supplementation provided significant restoration in both groups elevating the GSH content up to $~ 75-80 \%$ of the NT-C levels.

\section{ROS production}

Fig. 3 illustrates the intracellular production of ROS in MA-10 cells at different time points. As shown in Fig. 3A, there was no significant ROS production in NT-C cells at time point $30 \mathrm{~min}$, but after $60 \mathrm{~min}$ of
A
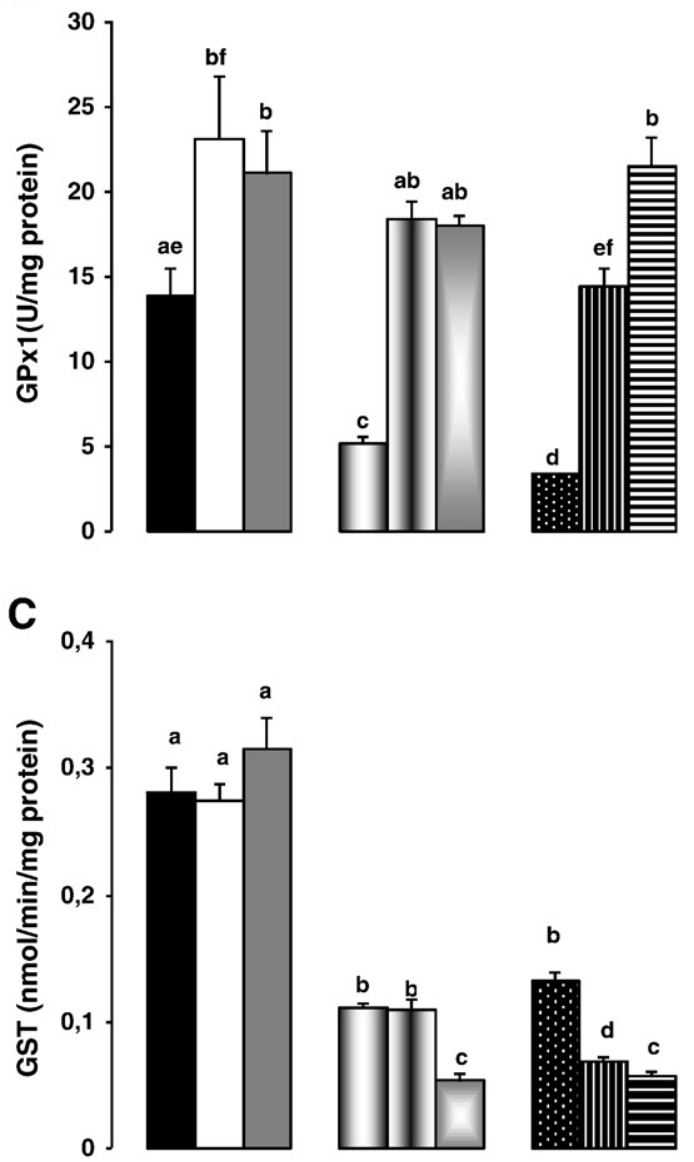

B

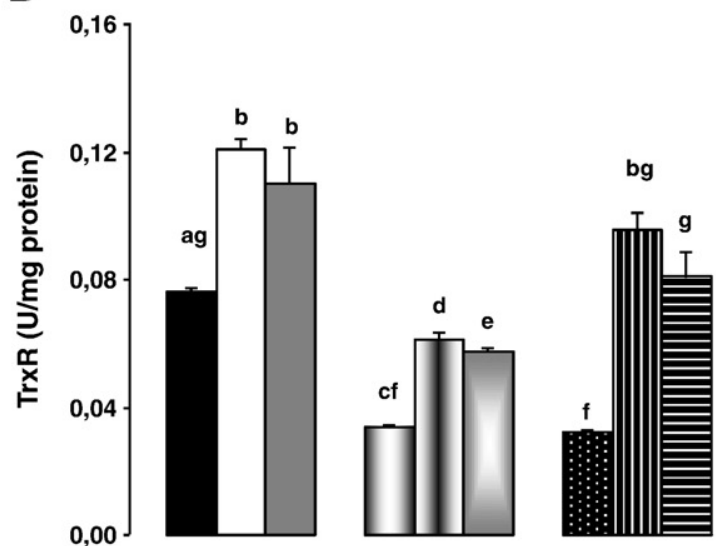

D

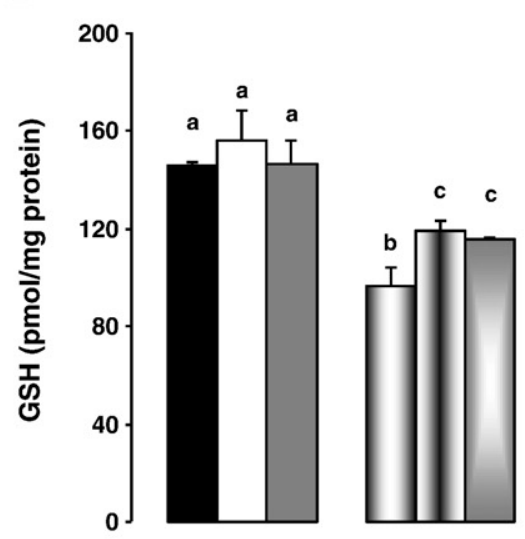

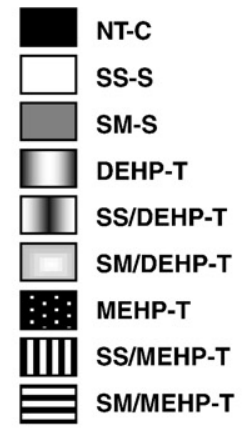

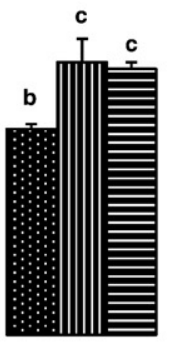

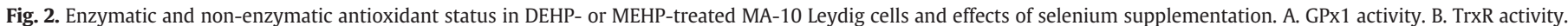

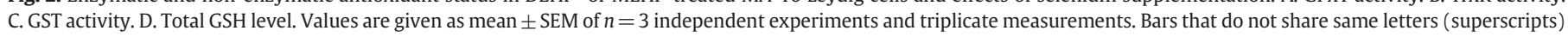

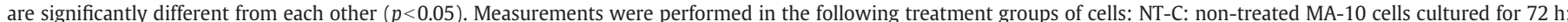

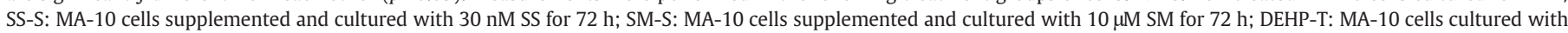

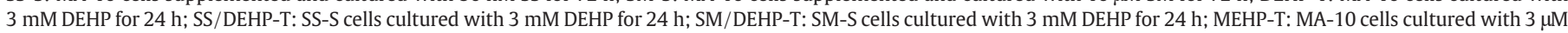
MEHP for 24 h; SS/MEHP-T: SS-S cells cultured with $3 \mu \mathrm{M}$ MEHP for 24 h; SM/MEHP-T: SM-S cells cultured with $3 \mu \mathrm{M}$ MEHP for 24 h. 
incubation ROS production increased 1.7-fold. Presence of Se in SS or SM forms did not change the intracellular ROS levels when compared to NT-C cells neither after 30 min nor 60 min of incubations.

DEHP and MEHP exposures caused strongly amplified production of ROS. At time point $30 \mathrm{~min}$, ROS levels of the DEHP-exposed cells increased significantly, reaching $\sim 2.4$-fold of the level of time zero, and after 60 min of incubation the increase was $~ 3.5$-fold (Fig. 3B). Whereas in MEHP-treated MA-10 cells, very sharp elevation of ROS production was observed reaching $\sim 2.3$-fold and $\sim 11.4$-fold of the initial level, at time points $30 \mathrm{~min}$ and $60 \mathrm{~min}$, respectively (Fig. 3C).

A

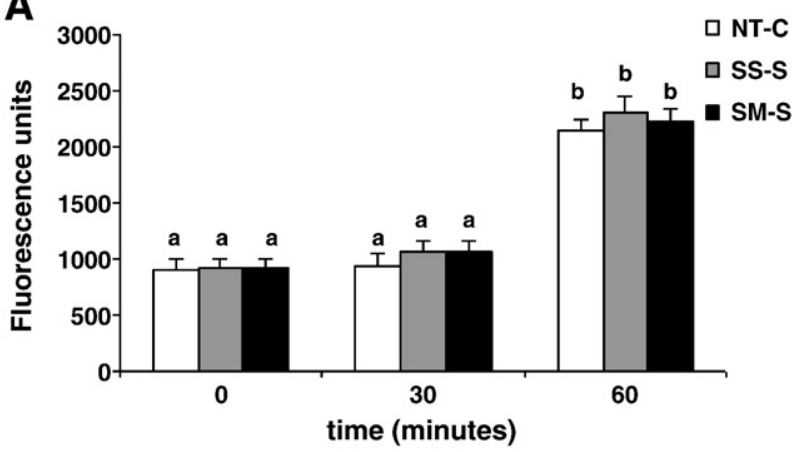

B
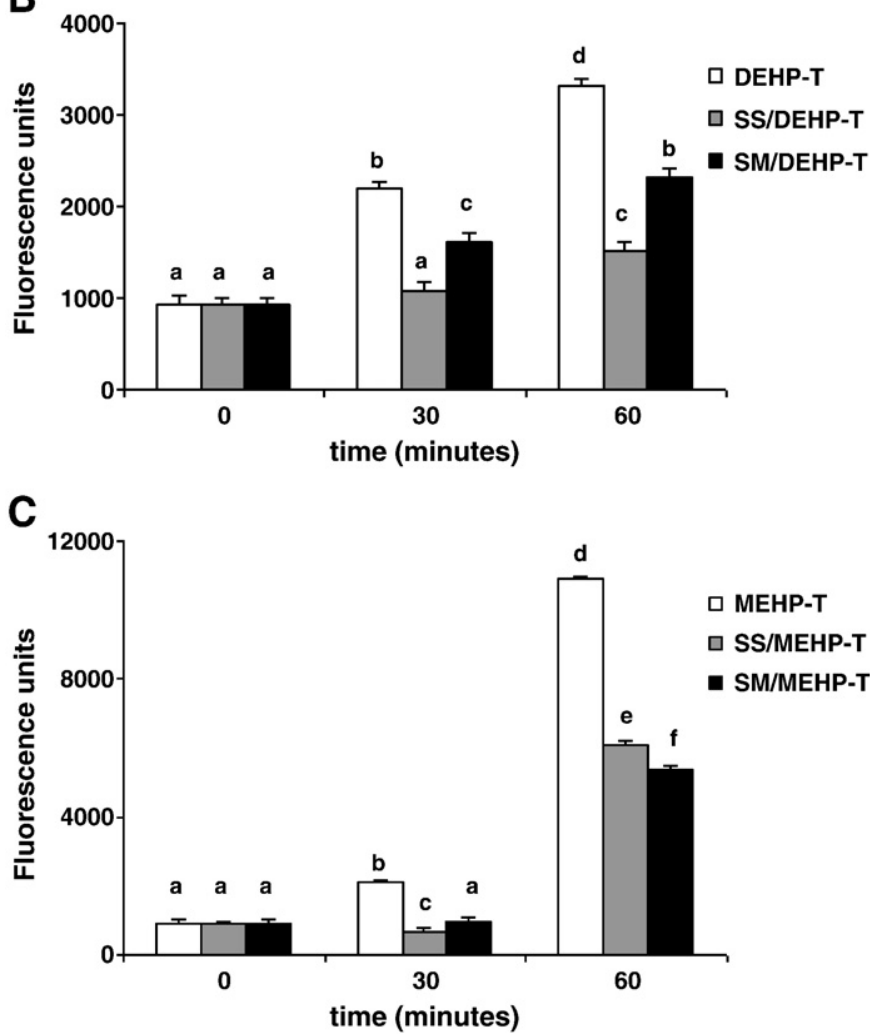

Fig. 3. ROS production in DEHP- or MEHP-exposed MA-10 Leydig cells and effects of selenium supplementation. Total intracellular ROS was measured using peroxide sensitive fluorescent probe $\mathrm{CM}-\mathrm{H}_{2} \mathrm{DCFA}$ at 0,30 , and $60 \mathrm{~min}$. Values are given as mean \pm SEM of $n=3$ independent experiments and triplicate measurements. Bars that do not share same letters (superscripts) are significantly different from each other $(p<0.05)$. A. ROS production in cells without phthalate exposure (NT-C: non-treated MA-10 cells cultured for $72 \mathrm{~h}$; SS-S: MA-10 cells supplemented and cultured with $30 \mathrm{nM} \mathrm{SS}$ for $72 \mathrm{~h}$; SM-S: MA-10 cells supplemented and cultured with $10 \mu \mathrm{M}$ SM for $72 \mathrm{~h}$ ). B. ROS production in DEHP-treated cells (DEHP-T: MA-10 cells cultured with 3 mM DEHP for 24 h; SS/DEHP-T: SS-S cells cultured with 3 mM DEHP for 24 h; SM/DEHP-T: SM-S cells cultured with $3 \mathrm{mM}$ DEHP for $24 \mathrm{~h}$ ). C. ROS production in MEHP-treated cells (MEHP-T: MA-10 cells cultured with $3 \mu \mathrm{M}$ MEHP for $24 \mathrm{~h}$; SS/MEHP-T: SS-S cells cultured with $3 \mu \mathrm{M}$ MEHP for $24 \mathrm{~h}$; SM/MEHP-T: SM-S cells cultured with $3 \mu \mathrm{M}$ MEHP for $24 \mathrm{~h}$ ).
Both SS and SM supplementations were highly effective against the generation of intracellular ROS induced by both phthalate derivatives. In the presence of SS, ROS levels in DEHP-exposed cells decreased $\sim 2$-fold and $\sim 2.2$-fold, at 30 and 60 min, respectively. Whereas, the decrease with SM supplementation was $\sim 1.4$-fold at both time points (Fig. 3B).

In MEHP-T cells, SS supplementation caused $~ 3.5$-fold and $\sim 1.8$-fold decrease of ROS production at $30 \mathrm{~min}$ and $60 \mathrm{~min}$, respectively. Whereas presence of Se in SM form provided $~ 2.6$-fold and $~ 2.1$-fold decrease of ROS generation at $30 \mathrm{~min}$ and $60 \mathrm{~min}$, respectively (Fig. 3C).

\section{p53 immunocytochemistry}

As shown in Table 1, p53 protein expression in Se treated MA-10 cells was significantly lower ( 65\%) than the steady state level of the control cells (NT-C), and there was no difference between the protective effects of SS and SM. In MA-10 cells exposed to an $\mathrm{IC}_{50}$ dose of DEHP, p53 expression was not induced. But a significant induction ( 1.7 -fold) of p53 expression was observed in MA-10 cells exposed to an $\mathrm{IC}_{50}$ dose of MEHP. SS or SM supplementation enabled the phthalate-exposed cells to maintain the p53 expression almost at the basal level, or even lower as in the case of SS/DEHP-T cells. Fig. 4 shows the images of p53 expression in MEHP-treated cells along with the images of control groups.

\section{DNA damage-Comet assay}

Fig. 5 shows the results of the alkaline Comet assay performed on MA-10 cells exposed to an IC 50 dose of DEHP ( $3 \mathrm{mM})$ or MEHP $(3 \mu \mathrm{M})$ in the presence or absence of Se, with the illustrations of the examples of comet images.

Both DEHP and MEHP produced high level of DNA damage as evidenced by significantly increased tail intensity (\%) ( 3.4-fold and $\sim 3.8$-fold, respectively), and tail moment ( 4.2-fold and $\sim 3.8$-fold, respectively) compared to non-treated MA-10 cells. The difference between the DNA damaging effects of the parent compound and the metabolite was insignificant.

Se supplementation itself did not cause any alteration on the steady state levels of the DNA damage biomarkers of MA-10 cells. But Se was highly effective to decrease the genotoxic effects of phthalate esters. Increased tail \% intensities by DEHP and MEHP exposure were lowered 50-55\% with SS supplementation, whereas SM treatment

Table 1

p53 immunocytochemistry scorings for the study groups.

\begin{tabular}{lc}
\hline Study group & \% of nuclear p53 stained cells \\
\hline NT-C & $8.77^{\mathrm{a}}$ \\
SS-S & $2.99^{\mathrm{b}}$ \\
SM-S & $3.14^{\mathrm{b}}$ \\
DEHP-T & $9.38^{\mathrm{a}}$ \\
SS/DEHP-T & $6.72^{\mathrm{c}}$ \\
SM/DEHP-T & $8.76^{\mathrm{a}}$ \\
MEHP-T & $15.03^{\mathrm{d}}$ \\
SS/MEHP-T & $8.86^{\mathrm{a}}$ \\
SM/MEHP-T & $9.85^{\mathrm{a}}$ \\
\hline
\end{tabular}

p53 expression was determined using EnVision Plus staining kit as described in Materials and Methods. Results were given as the percentage of p53 nuclear staining (mean \pm SEM). Means that do not share same letters (superscripts) are significantly different from each other $(p<0.05)$.

Measurements were performed in the following treatment groups of cells: NT-C: nontreated MA-10 cells cultured for $72 \mathrm{~h}$; SS-S: MA-10 cells supplemented and cultured with $30 \mathrm{nM}$ SS for $72 \mathrm{~h}$; SM-S: MA-10 cells supplemented and cultured with $10 \mu \mathrm{M}$ SM for $72 \mathrm{~h}$; DEHP-T: MA-10 cells cultured with $3 \mathrm{mM}$ DEHP for $24 \mathrm{~h}$; SS/DEHP-T: SS-S cells cultured with $3 \mathrm{mM}$ DEHP for $24 \mathrm{~h}$; SM/DEHP-T: SM-S cells cultured with $3 \mathrm{mM}$ DEHP for $24 \mathrm{~h}$; MEHP-T: MA-10 cells cultured with $3 \mu \mathrm{M}$ MEHP for $24 \mathrm{~h}$; SS/MEHP-T: SS-S cells cultured with $3 \mu \mathrm{M}$ MEHP for $24 \mathrm{~h}$; SM/MEHP-T: SM-S cells cultured with $3 \mu \mathrm{M}$ MEHP for $24 \mathrm{~h}$. 


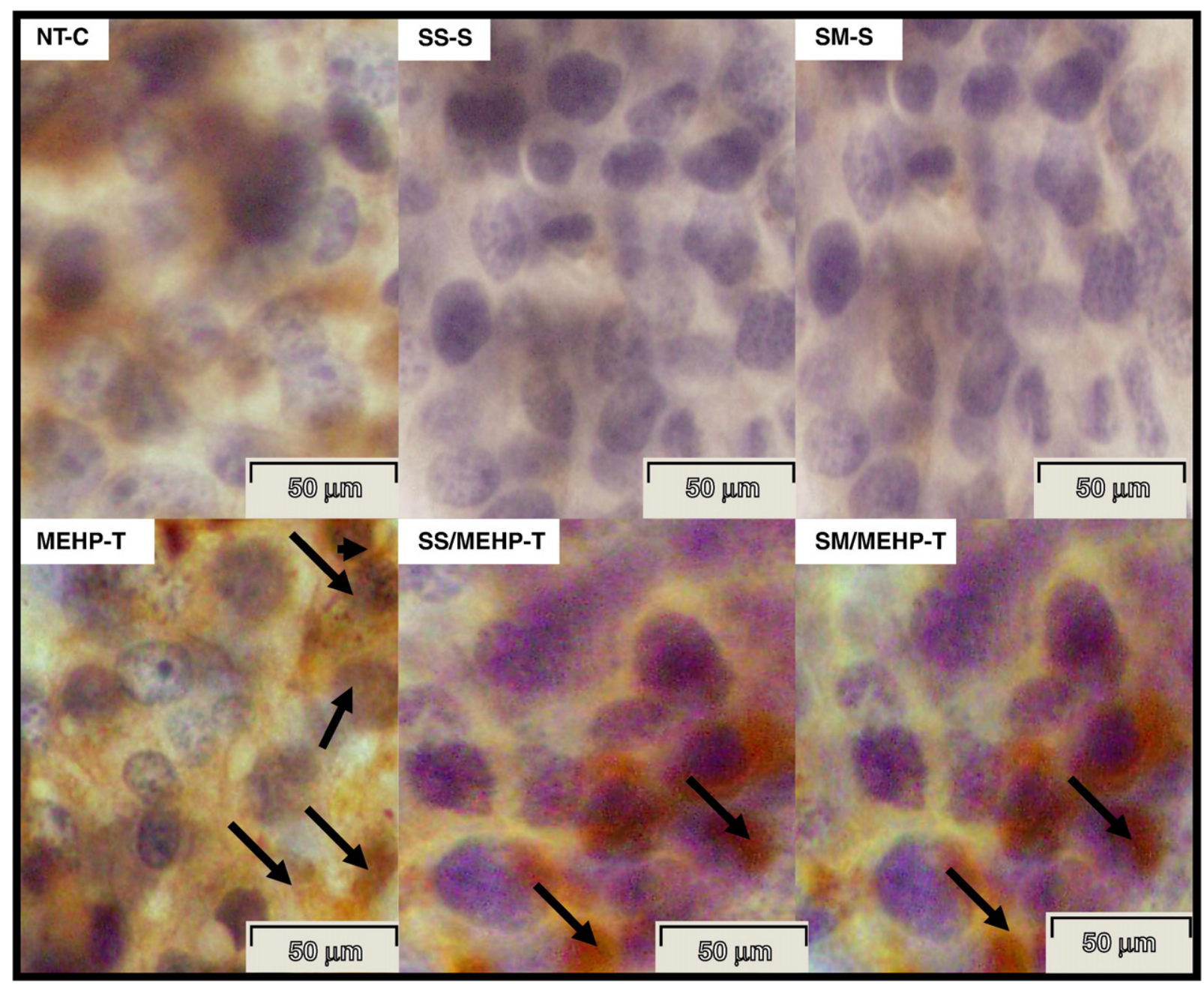

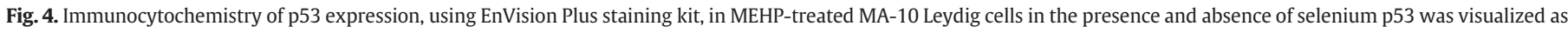

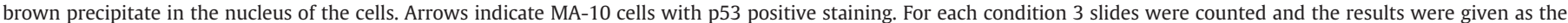

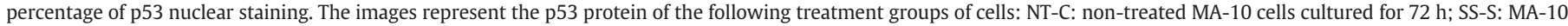

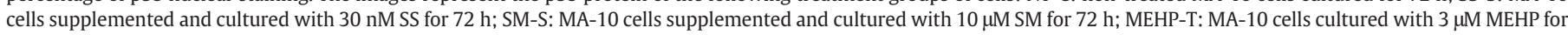
$24 \mathrm{~h}$; SS/MEHP-T: SS-S cells cultured with $3 \mu \mathrm{M}$ MEHP for $24 \mathrm{~h}$; SM/MEHP-T: SM-S cells cultured with $3 \mu \mathrm{M}$ MEHP for $24 \mathrm{~h}$.

provided $\sim 30-40 \%$ protection. SS decreased the tail moments of the DEHP- or MEHP-exposed cells by 55-65\%, whereas the protective effect of SM on tail moments was significantly lower than SS as being $\sim 45 \%$ and $\sim 34 \%$ for the effects of DEHP and MEHP, respectively. However, both SS and SM reduced the tail moments of the DEHP- and MEHP-exposed cells down to the levels that were not significantly different than that of control cells.

\section{Discussion}

DEHP is a well-known peroxisome proliferator, and regarded as a non-classic type endocrine disruptor, that is, in contrast to the classical endocrine disrupters which interfere with endocrine process at the receptor level, alters reproductive function by affecting hormone synthesis (Akingbemi et al., 2004; Gazouli et al., 2002; Wilson et al., 2004). Exposures to DEHP or its main metabolite MEHP have been found to result in decreased testicular testosterone levels in mice, indicating that testosterone producing Leydig cells were also the target of the phthalates, besides Sertoli cells (Jones et al., 1993). In fact, inhibition of LH-stimulated testosterone secretion by MEHP in MA-10 Leydig cells was previously demonstrated (Freeman and Ascoli, 1983; Gazouli et al., 2002), and co-administration of testosterone with DEHP was reported to prevent the DEHP-induced testicular toxicity (Parma et al., 1987).
The induction of oxidative stress was previously suggested to represent a common mechanism in endocrine disruptor-mediated dysfunction, specific to certain testicular cells (Latchoumycandane and Mathur, 2002). Recent data have also shown that phthalates were able to produce free radicals by several pathways in germ cells including activation of PPAR $\alpha$, suggesting the possibility that oxidative stress and mitochondrial dysfunction in germ cells may contribute to phthalate-induced disruption of spermatogenesis (Gazouli et al., 2002; Suna et al., 2007). DEHP treatment, indeed, was reported to provoke oxidative stress as measured by increases in ROS in subsequently isolated rat spermatocytes (Kasahara et al., 2002). MEHP was reported to increase peroxiredoxin 3 and cyclooxygenase2 levels in germ cells indicating that the disruption of cellular redox mechanisms in spermatocytes (Onorato et al., 2008). Thus, at least one of the mechanisms underlying the reproductive toxicity of DEHP might be the induction of intracellular ROS and/or to cause alterations on intracellular enzymatic and non-enzymatic antioxidants, thereby to produce oxidative stress.

In the current study, using a well-established cell model, the MA10 mouse Leydig tumor cell line (Ascoli, 1981), the effects of direct exposure to DEHP and MEHP on Leydig cells, including cytotoxicity, genotoxicity and oxidative stress potential were investigated. MA-10 cells produce more progesterone than testosterone, but otherwise resemble normal Leydig cells (Mylchreest et al., 2002). They contain 
A

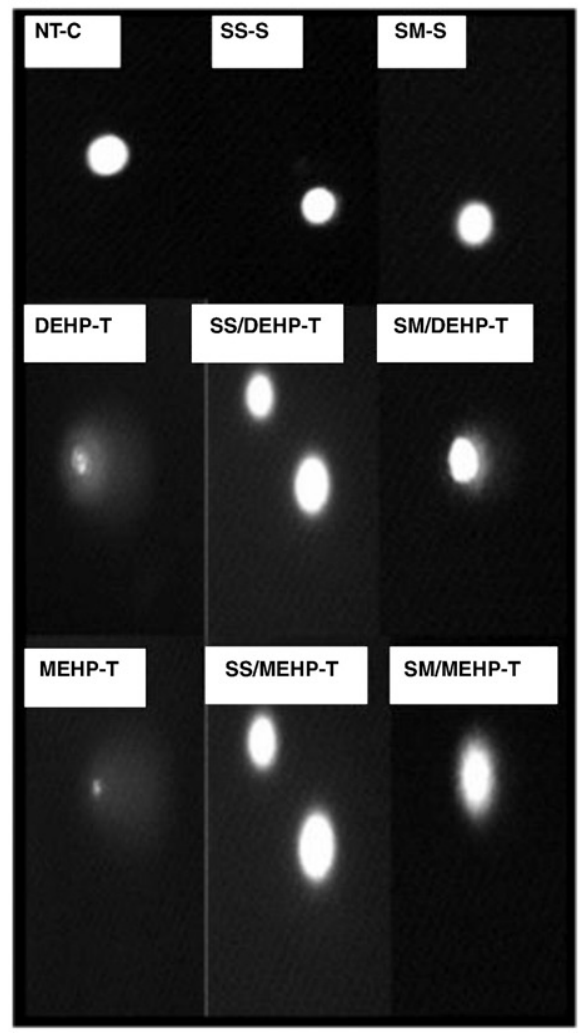

B

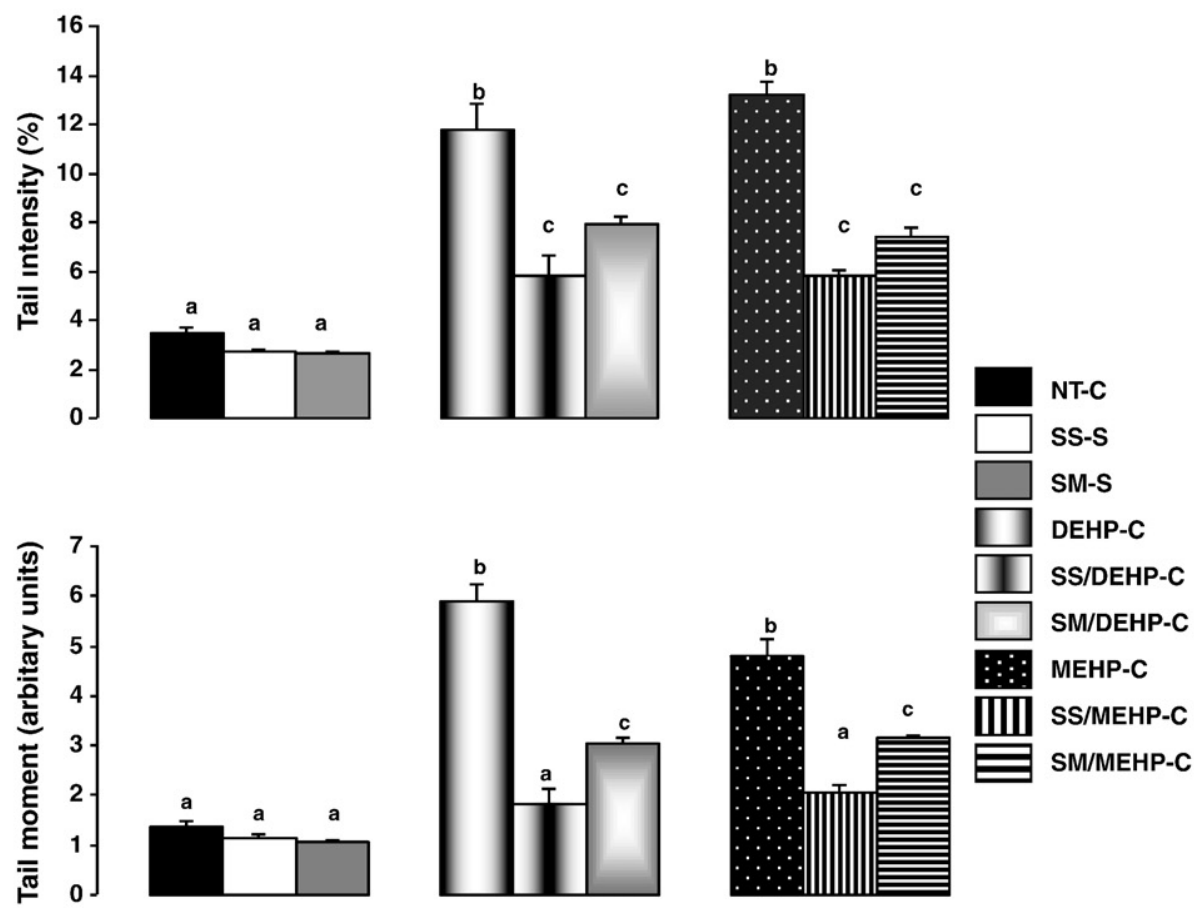

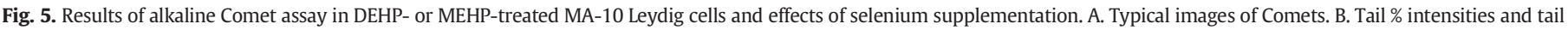

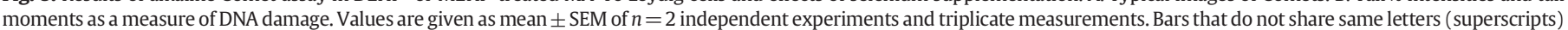

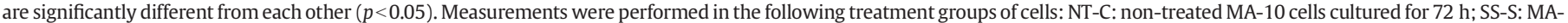

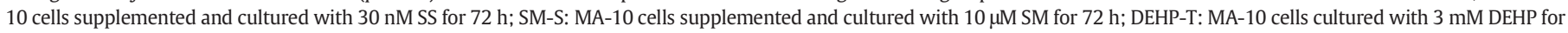

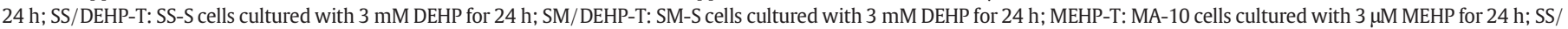
MEHP-T: SS-S cells cultured with $3 \mu \mathrm{M}$ MEHP for $24 \mathrm{~h}$; SM/MEHP-T: SM-S cells cultured with $3 \mu \mathrm{M}$ MEHP for $24 \mathrm{~h}$.

both PPAR $\alpha$ and PPAR $\beta$, but not PPAR $\gamma$ (Dostal et al., 1988) as in the case of both Leydig and Sertoli cells of adult rats (Braissant et al., 1996).

Cytotoxicity, in the current study, was assessed using the MTT assay of mitochondrial integrity, a marker of cell viability. Significantly decreased cell viability was observed with $10 \mu \mathrm{M}$ and higher concentrations of DEHP. However, in agreement with earlier reports (Kambia et al., 2004), and with the results of our recent study conducted on LNCaP cells (Erkekoglu et al., 2010), cytotoxicity of MEHP was much higher than the parent compound, indicating the toxicity of DEHP is mostly based on the activity of MEHP. In fact, the difference between the $\mathrm{IC}_{50}$ values of the two agents was almost three orders of magnitude. However, the toxicity range of MEHP reported by two studies was significantly different than ours. Dees et al. (2001) examined the effects of various concentrations of MEHP on progesterone production, cell viability, protein content and cell morphology in MA-10 cells in the presence of hCG, and they observed no effect for the range of $0.3 \mu \mathrm{M}$ to $1 \mathrm{mM} \mathrm{MEHP}$, and markedly decreased cell viability (to $16 \%$ ) at $3 \mathrm{mM}-10 \mathrm{mM}$. In a very recent study which was published during the submission of the present study, it was also reported that at concentrations as high as $300 \mu \mathrm{M}$, MEHP was not toxic to the MA-10 cells (Fan et al., 2010). The reason for this discrepancy is not known, however, might be due to the differences in the experimental designs, the cell culturing conditions, particularly cell density/number, and source and purity of the MEHP, and may be the presence or absence of hCG.

Se supplementation was highly effective in maintaining the viability of MA-10 cells exposed to various doses of DEHP, and MEHP. The protective effect of $30 \mathrm{nM}$ SS supplementation on the cell survival was almost as the same level as the protection provided by 10 $\mu \mathrm{M}$ SM. Thus, more SM was required to achieve a similar effect as was obtained with the more bioavailable form of Se, selenite. The doses of Se in the form of SS and SM used in this study were chosen from preliminary experiments (not shown) as the concentrations did not inhibit cell growth and did not cause cytotoxicity, but result in maximal GPx1 induction after $72 \mathrm{~h}$ of incubation. These concentrations were also in the same range as those concentrations of SS and SM that were shown previously with the same properties for several other cell types (Bhamre et al., 2003; Chu et al., 1990; Mansur et al., 2000). SS is commonly used for cell culture and animal studies, and $\mathrm{SM}$ is the most common form of Se obtained from the diet. SM is converted to $\mathrm{H}_{2} \mathrm{Se}$ through transulfuration and $\beta$-lyase cleavage, whereas SS interacts with GSH to form GSSeSG which is subsequently reduced to $\mathrm{H}_{2} \mathrm{Se}$. $\mathrm{H}_{2} \mathrm{Se}$ derived via both pathways can be converted to selenophosphate which is then used in the synthesis of selenoproteins. This difference in Se metabolism is likely to account for the greater efficiency of SS over SM, as has been reported for a variety of cell types (Zhuo et al., 2009).

Se plays a critical role in testis, sperm, and reproduction. In rodent testis, Se concentrations are typically higher than for any other tissue except kidney, and unlike most other tissues except brain and endocrine tissues, generally do not decrease even with prolonged Se deficiency, showing that Se is preferentially maintained in the rodent testis (Behne and Höfer-Bosse, 1984; Behne et al., 1988). Selenoprotein $\mathrm{P}$ (Sepp1) is the responsible molecule for the targeted trafficking of Se to testis (Hill et al., 2003; Schomburg et al., 2003). When Se supply is limited due to Se deficiency, incoming Se as Sepp1 would be delivered preferentially to the Sertoli cells, thereby maintaining testis Se 
concentrations. Selenoproteins identified in testis are Sepp1, mitocondrial and cytosolic TrxR, GPx1, and GPx4 as the most abundantly present selenoprotein in rat testis (Maiorino et al., 2006; Roveri et al., 1992; Tramer et al., 1998). Leydig cells, on the other hand, do not contain appreciable Sepp1 protein (Olson et al., 2007), but they are the major cells expressing Sepp1 mRNA in testis (Koga et al., 1998; Steinert et al., 1998). GPx1 has been implicated in antioxidant defense in Leydig cells that are presumed to produce $\mathrm{H}_{2} \mathrm{O}_{2}$ during steroid hormone synthesis (Peltola et al., 1996). It is thought that the seminiferous epithelium and mature sperm also require a particularly efficient protection against oxidative stress (Tramer et al., 1998; Zini and Schlegel, 1997). GPx1, as the selenoperoxidase most efficient in $\mathrm{H}_{2} \mathrm{O}_{2}$ reduction would indeed be the enzyme of choice to meet this demand (Ursini et al., 1995).

The induction of GPx1 activity in MA-10 cells that we observed with Se supplementation was previously demonstrated in several tissues, and reported as being due to enhanced translation and not transcription of the enzyme (Hu and Diamond, 2003). The Se-containing cytosolic enzyme GPx1 plays an important role in the defense mechanisms of mammals against damage by catalyzing the reduction of $\mathrm{H}_{2} \mathrm{O}_{2}$ and a large variety of hydroperoxides (Ursini et al., 1995). GPx1, in addition to affecting GSH/GSSG, controls the cellular content of $\mathrm{H}_{2} \mathrm{O}_{2}$ (or other organic hydroperoxides) and $\mathrm{NADPH} / \mathrm{NADP}^{+}$, so that it may regulate the cellular redox status. Taking into account the critical importance of GPx1 activity and expression, the GPx1 activity reducing effects of DEHP $(\sim 2.5$-fold) and MEHP ( 4-fold) shown in this study in MA-10 cells might be considered as having important implications in testicular function. Intracellular GSH is a key redox regulator that is crucial for multiple biological functions. The decrease of GSH we observed in phthalate treated cells was further supportive of the occurrence of oxidative stress and disturbance of the intracellular redox equilibrium, because removal of $\mathrm{H}_{2} \mathrm{O}_{2}$ by GPx1 requires $\mathrm{GSH}$ as a cofactor. Loss of GSH also occurs through conjugation to endogenous and exogenous electrophilic centers in reactions catalyzed by GSTs, the enzymes capable of detoxifying genotoxic electrophilic compounds by catalyzing their conjugation to GSH, and thus inactivate several environmental chemicals (Hayes and Pulford, 1995). However, in this study the activity of cytosolic GST was found to be reduced more than 50\% in DEHP, and MEHP-treated cells, indicating that the phthalate exposure disturbed the GST expression and/or activity in MA-10 cells as it disturbed GPx1. Se supplementation was not effective in restoring the GST activity and even lowered more, a finding that remained to be explained.

The Trx system, together with TrxR enzymes and NADPH, comprises an important defense system against oxidative stress and involved in many biological processes, such as DNA metabolism and repair, apoptosis, protein folding and degradation, regulation of several transcription factors and signal transduction (Björnstedt et al., 1997; Watson et al., 2004). Multiple TrxR enzymes are present, and cytosolic TrxR is a predominant form known for its antioxidant properties. Like GPx1, it plays a role in reducing oxidative species either directly or by regeneration of cellular antioxidants (Xia et al., 2003), and maintain the redox balance in the cell (Mustacich and Powis, 2000). Available data also indicate that cytosolic TrxR is regulated by the redox state of the cell (Gandin et al., 2009), and its specific activity is highly sensitive to concentration of Se in cellular milieu. Our findings showing $\sim 2$.4-fold decrease in cytosolic TrxR activity by both DEHP and MEHP exposures and significant restoration by Se supplementation, thus, provided more evidence for the alterations of cellular redox state induced by these two phthalates. Interestingly, protection by Se supplementation was complete only in MEHP-exposed cells. Our results also suggested the possibility that the decrease of TrxR activity contributes to the cytotoxicity of DEHP, and MEHP in MA-cells, as TrxR is essential for the normal growth of the cell, and inhibition of TrxR activity to below normal level has been reported to cause inhibited cell growth (Mustacich and Powis, 2000).

Various recent data have shown that ROS were involved in the modulation of cell redox state, and redox regulation of protein functions is now accepted as an additional regulatory mechanism of normal cell physiology (D'Autreaux and Toledano, 2007; Veal et al., 2007). Thus, ROS recently gained attention as important second messengers. However, excessive production of ROS may lead to oxidative stress, loss of cell function, and cell death by apoptosis or necrosis (Nose, 2000). The increased intracellular ROS production with phthalate exposure in the current study, along with the observation of decrease in intracellular GSH level, is the predominant evidence of a shift in the redox equilibrium towards oxidation, thus occurrence of oxidative stress. In agreement with our results, Fan et al. (2010) also observed an increase in ROS generation with MEHP exposure in MA-10 cells, and demonstrated that the increase of ROS production even with the highest concentration of MEHP $(300 \mu \mathrm{M})$ used in their study was blocked by preincubation of the cells with $\mathrm{N}$ acetylcysteine (NAC). In this very recent study, the authors suggested that the MEHP-induced expression of Cyp1a1 might be associated with the excess ROS generation.

Alteration of cell redox status by ROS can also change thiol groups in proteins and alter the activation of cell signaling proteins (Dalton et al., 1999; Finkel, 1998). p53 tumor suppressor protein is one of those various cell signaling proteins and known to be redox sensitive (Hainaut and Milner, 1993). When cells are exposed to oxidative stress, p53 is expressed at high levels by post-translational modifications (Burns and El-Deiry, 1999). These modifications occur rapidly and lead to the activation of p53, resulting in cell cycle arrest or apoptosis. Therefore, ROS are reported to function as p53 activators or p53 downstream effectors (Zhao et al., 2006). In fact, our results showed significant increase in nuclear p53 expression in MEHP-exposed cells further evidencing the alteration of intracellular redox state by phthalate exposure. Thus, our data suggested that MEHP, the main metabolite of DEHP, and possibly at proper doses DEHP itself induce nuclear p53 activation by producing ROS to activate p53. Determination of nuclear p53 is a good indicator of cell cycle arrest or apoptosis, because after the transfer of p53 to nucleus or after its overexpression, it is bound to the promoter regions of several genes including p21, thus, p53 acts as a transcriptional regulator (Ozturk et al., 2009). The ultimate results of all these alterations were the modulation of redox sensitive enzymes, DNA damage as evidenced with the results of alkaline Comet assay, and decreased cell viability. Our data also showed that, at the dose levels and forms we used, Se supplementation was protective against those adverse effects of DEHP and MEHP suggesting that Se exerted its protective effect by regulating the intracellular redox equilibrium of MA-10 cells.

Thus, the results of this study clearly showed the genotoxic potential of DEHP, and its main metabolite MEHP in MA-10 Leydig cells. This might have a contributory role on the overall effects of these compounds which are known as nongenotoxic rodent carcinogens (Rusyn et al., 2006). On the other hand, Se is known as bimodal in nature. At low concentrations, Se compounds are antigenotoxic and anticarcinogenic, whereas at high concentrations, they are mutagenic, toxic, and possibly carcinogenic (Letavayová et al., 2006). In this regard, it appears that the doses and the chemical forms of Se we used in this study were appropriate, did not exert any genotoxicity, but provided protection against the genotoxic effects of DEHP and MEHP on MA-10 cells at doses used within the study. The protection of DNA damages by Se might be through its involvement in DNA repair, but may also be due to a preventive effect in relation to its intracellular redox modulation.

In conclusion, the overall results of this study demonstrated the cytotoxicity and genotoxicity of DEHP, and its main metabolite MEHP in MA-10 mouse Leydig tumor cells indicating the oxidative stress induction as a main mechanism. Oxidative stress might also be one of the mechanisms underlying the testicular testosterone suppressing effect in Leydig cells, and in turn, the reproductive toxicity of DEHP. Generated data also emphasized the critical role of Se in modulation of the redox state in the testicular cells and the importance of the appropriate Se status. Therefore, it will be meaningful to study the consequences of oxidative stress on the steroidogenic functions of the MA-10 Leydig cells and particularly the primary Leydig cells; to 
examine whether there is a link between oxidative stress, cytotoxicity, genotoxicity and functional role of those cells; and the regulatory effects of various doses of Se.

\section{Acknowledgments}

The authors would like to thank Prof. Dr. Mario Ascoli for generously providing the MA-10 mouse Leydig tumor cells. Pınar Erkekoğlu, PhD, is a receiver of Erasmus and CEA grants and completed this work in INAC/ $\mathrm{SCIB} / \mathrm{LAN}, \mathrm{CEA}$ in Grenoble, France. This study was presented as a poster in XII International Congress of Toxicology - IUTOX 2010, Barcelona, Spain.

\section{References}

Akerboom, T.P., Sies, H., 1981. Assay of glutathione, glutathione disulfide, and glutathione mixed disulfides in biological samples. Meth. Enzymol. 77, 373-382.

Akingbemi, B.T., Ge, R., Klinefelter, G.R., Zikrin, B.R., Hardy, M.P., 2004. Phthalateinduced Leydig cell hyperplasia is associated with multiple endocrine disturbances. Proc. Natl Acad. Sci. USA 101, 775-780.

Arner, E.S., Zhong, L., Holmgren, A., 1999. Preparation and assay of mammalian thioredoxin and thioredoxin reductase. Meth. Enzymol. 300, 226-239.

Ascoli, M., 1981. Characterization of several clonal lines of cultured Leydig tumor cells: gonadotropin receptors and steroidogenic responses. Endocrinology 108, 88-95.

Behne, D., Höfer-Bosse, T., 1984. Effects of a low selenium status on the distribution and retention of selenium in the rat. J. Nutr. 114, 1289-1296.

Behne, D., Hilmert, H., Scheid, S., Gessner, H., Elger, W., 1988. Evidence for specific selenium target tissues and new biologically important selenoproteins. Biochim. Biophys. Acta 966, 12-21.

Bhamre, S., Whitin, J.C., Cohen, H.J., 2003. Selenomethionine does not affect PSA secretion independent of its effect on LNCaP cell growth. Prostate 54, 315-321.

Björnstedt, M., Kumar, S., Björkhem, L., Spyrou, G., Holmgren, A., 1997. Selenium and the thioredoxin and glutaredoxin systems. Biomed. Environ. Sci. 10, 271-279.

Braissant, O., Foufelle, F., Scotto, C., Duaca, M., Wahli, W., 1996. Differential expression of peroxisome proliferator-activated receptors (PPARs): tissue distribution of PPAR-alpha, -beta, and -gamma in the adult rat. Endocrinology 137, 354-366.

Burns, T.F., El-Deiry, W.S., 1999. The p53 pathway and apoptosis. J. Cell. Physiol. 181, 231-239.

Chandrasekaran, Y., Richburg, J.H., 2005. The p53 protein influences the sensitivity of testicular germ cells to mono-(2-ethylhexyl) phthalate-induced apoptosis by increasing the membrane levels of Fas and DR5 and decreasing the intracellular amount of c-FLIP. Biol. Reprod. 72, 206-213.

Chu, F.F., Esworthy, R.S., Akman, S., Doroshow, J.H., 1990. Modulation of glutathione peroxidase expression by selenium: effect on human MCF-7 breast cancer cell transfectants expressing a cellular glutathione peroxidase cDNA and doxorubicinresistant MCF-7 cells. Nucleic Acids Res. 18, 1531-1539.

Clark, L.C., Cantor, K.P., Allaway, W.H., 1991. Selenium in forage crops and cancer mortality in US counties. Arch. Environ. Health 46, 37-42.

Combs Jr., G.F., Gray, W.P., 1998. Chemopreventive agents: selenium. Pharmacol. Ther. 79, 179-192.

Cory, A.H., Owen, T.C., Barltrop, J.A., Cory, J.G., 1991. Use of an aqueous soluble tetrazolium/ formazan assay for cell growth assays in culture. Cancer Commun. 3, 207-212.

Dalton, T.P., Shertzer, H.G., Puge, A., 1999. Regulation of gene expression by reactive oxygen. Annu. Rev. Pharmacol. Toxicol. 39, 67-101.

D'Autreaux, B., Toledano, M.B., 2007. ROS as signalling molecules: mechanisms that generate specificity in ROS homeostasis. Nat. Rev. Mol. Cell Biol. 8, 813-824.

Dees, J.H., Gazouli, M., Papadopoulos, V., 2001. Effect of mono-ethylhexyl phthalate on MA-10 Leydig tumor cell structure and function. Reprod. Toxicol. 15, 171-187.

Dostal, L.A., Chapin, R.E., Stefanski, S.A., Haris, M.W., Schwetz, B.A., 1988. Testicular toxicity and reduced Sertoli cell numbers in neonatal rats by di(2-ethylhexyl)phthalate and the recovery of fertility as adults. Toxicol. Appl. Pharmacol. 95, 104-121.

Doull, J., Cattley, R., Elcombe, C., Lake, B.G., Swenberg, J., Wilkinson, C., Van Williams, G., Gernert, M., 1999. A cancer risk assessment of di(2-ethylhexy1) phthalate: application of the new U.S. EPA risk assessment guidelines. Regul. Toxicol. Pharmacol. 29, 327-357.

Dröge, W., 2002. Free radicals in the physiological control of cell function. Physiol. Rev. 82, 47-95.

Erkekoglu, P., Rachidi, W., De Rosa, V., Giray, B., Favier, A., Hıncal, F., 2010. Protective effect of selenium supplementation on the genotoxicity of di(2-ethylhexyl) phthalate and mono(2-ethylhexyl)phthalate treatment in LNCaP cells. Free Radic. Biol. Med. 49, 559-566.

Fan, J., Traore, K., Li, W., Amri, H., Huang, H., Wu, C., Chen, H., Zirkin, B., Papadopoulos, V., 2010. Molecular mechanisms mediating the effect of mono-(2-ethylhexyl) phthalate on hormone-stimulated steroidogenesis in MA-10 mouse tumor Leydig cells. Endocrinology 151, 3348-3362.

Finkel, T., 1998. Oxygen radicals and signaling. Curr. Opin. Cell Biol. 10, 248-253.

Fisher, J.S., Macpherson, S., Marchetti, N., Sharpe, R.M., 2003. Human 'testicular dysgenesis syndrome': a possible model using in-utero exposure of the rat to dibutyl phthalate. Hum. Reprod. 18, 1383-1394.

Flohé, L., 2007. Selenium in mammalian spermiogenesis. Biol. Chem. 388, 987-995.

Flohé, L., Günzler, W.A., 1984. Assays of glutathione peroxidase. Meth. Enzymol. 105, 114-121.
Freeman, D.A., Ascoli, M., 1983. The low-density lipoprotein pathway of cultured Leydig tumor cells: utilization of low-density lipoprotein-derived cholesterol for steroidogenesis. Biochim. Biophys. Acta 754, 72-81.

Gandin, V., Nyström, C., Rundlöf, A.K., Jönsson-Videsäter, K., Schönlau, F., Hörkkö, J., Björnstedt, M., Fernandes, A.P., 2009. Effects of the antioxidant Pycnogenol on cellular redox systems in U1285 human lung carcinoma cells. FEBS J. 276, 532-540. Ganther, D.E., 1999. Selenium metabolism, selenoproteins and mechanisms of cancer prevention: complexities with thioredoixn reductase. Carcinogenesis 20, 1657-1666.

Gazouli, M., Yao, Z.X., Boujrad, N., Corton, J.C., Culty, M., Papadopoulos, V., 2002. Effect of peroxisome proliferators on Leydig cell peripheral-type benzodiazepine receptor gene expression, hormone-stimulated cholesterol transport, and steroidogenesis: role of the peroxisome proliferator-activator receptor alpha. Endocrinology 143, 2571-2583.

Ge, R.S., Chen, G.R., Tanrikut, C., Hardy, M.P., 2007. Phthalate ester toxicity in Leydig cells: developmental timing and dosage considerations. Reprod. Toxicol. 23, 366-373.

Grasso, P., Heindel, J.J., Powell, C.J., Reichert Jr., L.E., 1993. Effects of mono(2-ethylhexyl) phthalate, a testicular toxicant, on follicle-stimulating hormone binding to membranes from cultured rat Sertoli cells. Biol. Reprod. 48, 454-459.

Günzler, W.A., Kremers, H., Flohé, L., 1974. An improved coupled test procedure for glutathione peroxidase (EC 1-11-1-9-) in blood. Z. Klin. Chem. Klin. Biochem. 12, 444-481.

Habig, W.H., Pabst, M.J., Jakoby, W.B., 1974. Glutathion S-transferases, the first enzymatic step in mercapturic acid formation. Biol. Chem. 249, 7130-7139.

Hainaut, P., Milner, J., 1993. Redox modulation of p53 conformation and sequencespecific DNA binding in vitro. Cancer Res. 53, 4469-4473.

Hayes, J.D., Pulford, D.J., 1995. The glutathione S-transferase supergene family: regulation of GST and the contribution of the isoenzymes to cancer chemoprotection and drug resistance. Crit. Rev. Biochem. Mol. Biol. 30, 445-600.

Hill, K.E., Zhou, J., McMahan, W.J., Motley, A.K., Atkins, J.F., Gesteland, R.F., Burk, R.F., 2003. Deletion of selenoprotein P alters distribution of selenium in the mouse. J. Biol. Chem. 278, 13640-13646.

Hu, Y.J., Diamond, A.M., 2003. Role of glutathione peroxidase 1 in breast cancer: loss of heterozygosity and allelic differences in the response to selenium. Cancer Res. 63, 3347-3351.

Jones, H.B., Garside, D.A., Liu, R., Roberts, J.C., 1993. The influence of phthalate esters on Leydig cell structure and function in vitro and in vivo. Exp. Mol. Pathol. 58, 179-193.

Kambia, K., Dine, T., Gressier, B., Dupin-Spriet, T., Luyckx, M., Brunet, C., 2004. Evaluation of the direct toxicity of trioctyltrimellitate (TOTM), di(2-ethylhexyl) phthalate (DEHP) and their hydrolysis products on isolated rat hepatocytes. Int. J. Artif. Organs 27, 971-978

Kasahara, E., Sato, E.F., Miyoshi, M., Konaka, R., Hiramoto, K., Sasaki, J., Tokuda, M., Nakano, Y., Inoue, M., 2002. Role of oxidative stress in germ cell apoptosis induced by di(2-ethylhexyl)phthalate. Biochem. J. 365, 849-856.

Kavlock, R., Boekelheide, K., Chapin, R., Cunningham, M, Faustman, E., Foster, P., Golub, M., Henderson, R., Hinberg, I., Little, R., Seed, J., Shea, K. NTP-CERHR. Expert panel update on the reproductive and developmental toxicity of di(2-ethylhexyl) phthalate. 2005.(URL:http://cerhr.niehs.nih.gov/chemicals/dehp/DEHP-Monograph.pdf). (Novem-ber, 2006).

Kim, E., Giese, A., Deppert, W., 2009. Wild-type p53 in cancer cells: when a guardian turns into a blackguard. Biochem. Pharmacol. 77, 11-20.

Kitahara, J., Seko, Y., Imura, N., 1993. Possible involvement of active oxygen species in selenite toxicity in isolated rat hepatocytes. Arch. Toxicol. 67, 497-501.

Koga, M., Tanaka, H., Yomogida, K., Tsuchida, J., Uchida, K., Kitamura, M., Sakoda, S., Matsumiya, K., Okuyama, A., Nishimune, Y., 1998. Expression of selenoprotein-P messenger ribonucleic acid in the rat testis. Biol. Reprod. 58, 261-265.

Krieg, R.C., Dong, Y., Schwamborn, K., Knuechel, R., 2005. Protein quantification and its tolerance for different interfering reagents using the BCA-method with regard to 2D SDS PAGE. J. Biochem. Biophys. Meth. 65, 13-19.

Latchoumycandane, C., Mathur, P.P., 2002. Induction of oxidative stress in the rat testis after short-term exposure to the organochlorine pesticide methoxychlor. Arch. Toxicol. 76, 692-698.

Letavayová, L., Vlcková, V., Brozmanová, J., 2006. Selenium: from cancer prevention to DNA damage. Toxicology 227, 1-14.

Loff, S., Kabs, F., Witt, K., Sartoris, J., Mandl, B., Niessen, K.H., Waag, K.L., 2000. Polyvinylchloride infusion lines expose infants to large amounts of toxic plasticizers. J. Pediatr. Surg. 35, 1775-1781.

Loikkanen, J.J., Naarala, J., Savolainen, K.M., 1998. Modification of glutamate-induced oxidative stress by lead: the role of extracellular calcium. Free Radic. Biol. Med. 24, 377-384.

Maiorino, M., Roveri, A., Ursini, F., 2006. Selenium and male reproduction. Chapter 28 In: Hatfield, D.L., Berry, M.J., Gladyshev, V.N. (Eds.), Selenium. Its molecular biology and role in human health. Springer Science + Business Media, New York, pp. 323-331.

Mansur, D.B., Hao, H., Gladyshev, V.N., Korotkov, K.V., Hu, Y., Moustafa, M.E., El-Saadani, M.A., Carlson, B.A., Hatfield, D.L., Diamond, A.M., 2000. Multiple levels of regulation of selenoprotein biosynthesis revealed from the analysis of human glioma cell lines. Biochem. Pharmacol. 60, 489-497.

Mustacich, D., Powis, G., 2000. Thioredoxin reductase. Biochem. J. 346Pt (1), 1-8

Mylchreest, E., Sar, M., Wallace, D.G., Foster, P.M., 2002. Fetal testosterone insufficiency and abnormal proliferation of Leydig cells and gonocytes in rats exposed to di(nbutyl) phthalate. Reprod. Toxicol. 16, 19-28.

Noriega, N.C., Howdeshell, K.L., Furr, J., Lambright, C.R., Wilson, V.S., Gray Jr., L.E., 2009. Pubertal administration of DEHP delays puberty, suppresses testosterone production, and inhibits reproductive tract development in male Sprague-Dawley and Long-Evans rats. Toxicol. Sci. 111, 163-178.

Nose, K., 2000. Role of reactive oxygen species in the regulation of physiological functions. Biol. Pharm. Bull. 23, 897-903.

O'Brien, M.L., Spear, B.T., Glauert, H.P., 2005. Role of oxidative stress in peroxisome proliferator-mediated carcinogenesis. Crit. Rev. Toxicol. 35, 61-88. 
Oberley, T.D., Zhong, W., Szweda, L.I., Oberley, L.W., 2000. Localization of antioxidant enzymes and oxidative damage products in normal and malignant prostate epithelium. Prostate 44, 144-155.

Olson, G.E., Winfrey, V.P., Nagdas, S.K., Hill, K.E., Burk, R.F., 2007. Apolipoprotein E receptor-2 (ApoER2) mediates selenium uptake from selenoprotein $P$ by the mouse testis. J. Biol. Chem. 282, 12290-12297.

Onorato, T.M., Brown, P.W., Morris, P.L., 2008. Mono-(2-ethylhexyl) phthalate increases spermatocyte mitochondrial peroxiredoxin 3 and cyclooxygenase 2. J. Androl. 29, 293-303.

Ozturk, M., Arslan-Ergul, A., Bagislar, S., Senturk, S., Yuzugullu, H., 2009. Senescence and immortality in hepatocellular carcinoma. Cancer Lett. 286, 103-113.

Parma, D., Srivastava, S.P., Singh, G.B., Seth, P.K., 1987. Effect of testosterone on the testicular atrophy caused by di(2-ethylhexyl) phthalate (DEHP). Toxicol. Lett. 36, 297-308.

Peltola, V., Huhtaniemi, I., Metsa-Ketela, T., Ahotupa, M., 1996. Induction of lipid peroxidation during steroidogenesis in the rat testis. Endocrinology 137, 105-112.

Roveri, A., Casasco, A., Maiorino, M., Dalan, P., Calligaro, A., Ursini, F., 1992. Phospholipid hydroperoxide glutathione peroxidase of rat testis. Gonadotropin dependence and immunocytochemical identification. J. Biol. Chem. 267, 6142-6146.

Rusyn, I., Peters, J.M., Cunningham, M.L., 2006. Modes of action and species-specific effects of di-(2-ethylhexyl)phthalate in the liver. Crit. Rev. Toxicol. 36, 459-479.

Schomburg, L., Schweizer, U., Holtmann, B., Flohé, L., Sendtner, M., Köhrle, J., 2003. Gene disruption discloses role of selenoprotein $\mathrm{P}$ in selenium delivery to target tissues. Biochem. J. 370, 397-402.

Singh, N.P., McCoy, M.T., Tice, R.R., Schneider, E.L., 1988. A simple technique for quantitation of low levels of DNA damage in individual cells. Exp. Cell Res. 175, 184-191.

Steinert, P., Bächner, D., Flohé, L., 1998. Analysis of the mouse selenoprotein P gene. Biol. Chem. 379, 683-691.

Suna, S., Yamaguchi, F., Kimura, S., Tokuda, M., Jitsunari, F., 2007. Preventive effect of Dpsicose, one of rare ketohexoses, on di-(2-ethylhexyl) phthalate (DEHP)-induced testicular injury in rat. Toxicol. Lett. 173, 107-117.

Swan, S.H., 2008. Environmental phthalate exposure in relation to reproductive outcomes and other health endpoints in humans. Environ. Res. 108, 177-184.
Tice, R.R., Agurell, E., Anderson, D., Burlinson, B., Hartmann, A., Kobayashi, H., Miyamae Y., Rojas, E., Ryu, J.C., Sasaki, Y.F., 2000. Single cell gel/comet assay: guidelines for in vitro and in vivo genetic toxicology testing. Environ. Mol. Mutagen. 35 206-221.

Tramer, F., Rocco, F., Micali, F., Sandri, G., Panfili, E., 1998. Antioxidant systems in rat epididymal spermatozoa. Biol. Reprod. 59, 753-758.

Ursini, F., Maiorino, M., Brigelius-Flohé, R., Aumann, K.D., Roveri, A., Schomburg, D. Flohé, L., 1995. Diversity of glutathione peroxidases. Meth. Enzymol. 252, 38-53.

Ursini, F., Heim, S., Kiess, M., Maiorino, M., Roveri, A., Wissing, J., Flohé, L., 1999. Dua function of the selenoprotein PHGPx during sperm maturation. Science 85, 1393-1396.

Veal, E.A., Day, A.M., Morgan, B.A., 2007. Hydrogen peroxide sensing and signaling. Mol Cell 26, 1-14

Watson, W.H., Yang, X., Choi, Y.E., Jones, D.P., Kehrer, J.P., 2004. Thioredoxin and its role in toxicology. Toxicol. Sci. 78, 3-14.

Wilson, V.S., Lambright, C., Furr, J. Ostby, J. Wood, C., Held, G., Gray Jr., L.E, 2004 Phthalate ester-induced gubernacular lesions are associated with reduced insl3 gene expression in the fetal rat testis. Toxicol. Lett. 146, 207-215.

Xia, L., Nordman, T., Olsson, J.M., Damdimopoulos, A., Björkhem-Bergman, L., Nalvarte, I., Eriksson, L.C., Arnér, E.S., Spyrou, G., Björnstedt, M., 2003. The mammalian cytosolic selenoenzyme thioredoxin reductase reduces ubiquinone. A novel mechanism for defense against oxidative stress. Biol. Chem. 278, 2141-2146.

Zhang, Y.H, Lin, L, Liu, ZW. Jiang XZ, Chen, B.H., 2008. Disruption effects of monophthalate exposures on inter-Sertoli tight junction in a two-compartment culture model. Environ. Toxicol. 23, 302-308.

Zhao, R., Domann, F.E., Zhong, W., 2006. Apoptosis induced by selenomethionine and methioninase is superoxide mediated and p53 dependent in human prostate cancer cells. Mol. Cancer Ther. 5, 3275-3284.

Zhuo, P., Goldberg, M., Herman, L., Lee, B.S., Wang, H., Brown, R.L., Foster, C.B., Peters, U., Diamond, A.M., 2009. Molecular consequences of genetic variations in the glutathione peroxidase 1 selenoenzyme. Cancer Res. 69, 8183-8190.

Zini, A., Schlegel, P.N., 1997. Expression of glutathione peroxidases in the adult male rat reproductive tract. Fertil. Steril. 68, 689-695. 